\section{International Scientific Journal Theoretical \& Applied Science}

p-ISSN: 2308-4944 (print) e-ISSN: 2409-0085 (online)

Year: $2014 \quad$ Issue: $11 \quad$ Volume: 19

Published: $30.11 .2014 \quad$ http://www.T-Science.org
Sanobar Narzikulovna Akbarova Candidate of psychological sciences, Tashkent Pediatric Medical institute,

Uzbekistan sanobarakbarova@tashpmi.uz

Khatira Dadabayevna Aymetova Senior teacher, Tashkent Pediatric Medical institute, Uzbekistan

SECTION 21. Pedagogics. Psychology. Innovation in the field of education.

\title{
STUDYING THE ABILITIES TO NATURAL AND EXACT SCIENCES OF LYCEUM'S PUPILS OF TASHKENT CITY
}

Abstract: Research work is devoted to studying correlative connection between abilities to exact and natural sciences. It was revealed the close connection between ability to chemistry and both, exact and natural sciences. The further prospects of studying of person's abilities are shown.

Key words: ability, propensity, natural sciences, exact sciences, map of interests.

Language: English

Citation: Akbarova SN, Aymetova KD (2014) STUDYING THE ABILITIES TO NATURAL AND EXACT SCIENCES OF LYCEUM'S PUPILS OF TASHKENT CITY. ISJ Theoretical \& Applied Science 11 (19): $27-29$. doi: http://dx.doi.org/10.15863/TAS.2014.11.19.6

The professional ability, propensity and endowment of person were in the central attention of society and appreciated to a large extent during many centuries, as these psychological properties are essential factors which can lead a person to his successful professional activity.

Not everyone can estimate his or her potential possibility objectively and find suiting direct by means of professional activity without psychological help. That is why a lot of adult people in the society are occupied with the work where they can't realize their ability and propensity. This state is the main reason people's not to be satisfied with the work, as in the result, they can't achieve any success in their activity. So one of the important tasks of psychologists is the defining the potential professional ability, propensity and providing development of these properties.

Unfortunately, the problem of ability, propensity and endowment is not studied fully and completely yet. A method that can diagnose validly any ability and propensity which human may have does not exist yet [1, C.11]. In order to analyze possibility of psychological tests on ability and propensity we have provided research study on teenagers of lyceum in Tashkent city. We chose very popular method of ability study as "A map of interests" developed by Golomshtok E.A. [2]. There were 115 participants in our experiment. Further, we analyzed correlation link between received data by using computer program CSS. The correlative connection between exact sciences (Physics, Chemistry, Mathematics, Radio engineering and natural sciences (Medicine, Biology) is shown in the Table 1.

In the correlation table corresponding factors showed, that between physics and chemistry, mathematics, an electro-radio engineering there was a close connection, but here the physics had no connection with natural sciences. Indexes of three subjects compose the exact sciences, such as physics, mathematics and radio engineering did not have statistical connection with subjects of natural sciences. It means, activity in these areas did not demand similar cogitative operations (the analysissynthesis, generalization). The person with high propensity to the analysis-synthesis is considered as inclined to all exact sciences. And also, nonexistent connection of indicators of medicine and biology with the exact sciences on "A map of interests" leads to the conclusion that abilities in these directions do not cross. The interest to a chemistry occupied special place in this area. Chemistry indicators had strong statistical connection almost with all studied sciences, excluding mathematics. It means, that interest to chemistry was described as the perfect sphere including abilities both to the exact sciences, and to natural sciences in teenager's representation. In this connection, we consider, that ability to each exact subject should be studied in detailed aspect where the main accent is given to professiogram and psychogram. 
Correlative connection of interests to exact and natural sciences.

\begin{tabular}{|c|c|c|c|c|c|c|c|c|c|}
\hline 1 & 2 & 3 & 4 & 5 & 6 & 7 & 8 & & Physics \\
\hline & 422 & 650 & 574 & 884 & 174 & -007 & 099 & 1 & Chemistry \\
\hline & & 178 & 288 & 625 & 617 & 383 & 566 & 2 & Mathematics \\
\hline & & 433 & 772 & -021 & -105 & -068 & 3 & Radio engineering \\
\hline & & & & 728 & 096 & -186 & -041 & 4 & Sum of exact sciences \\
\hline & & & & & 286 & 034 & 187 & 5 & Biology \\
\hline & & & & & & & 882 & 7 & Medicine \\
\hline & & & & & & & & 8 & Sum of natural sciences \\
\hline
\end{tabular}

From this point of view, for example, for the expert in chemistry science it is demanded the following abilities: high level of concentration and stability of attention; ability to analyze and systematize an information of considerable quantity; ability to be engaged long time laborious work; a high noise stability; ability to perceive and distinguish a wide spectrum of colours and shades; good memory on symbols and signs; a fine manual motility; good sense of smell [3, p. 411]. And the mathematics, in turn, demands the following abilities, such as mathematical abilities; analytical abilities; logic thinking; a high level of development of concentration and stability of attention (ability to concentrate and long time to keep attention to a certain object or to a certain kind of activity); good development of short-term memory; memory on numbers and symbols; spatial imagination [3, p.180]. Apparently, despite the fact that correlation connection between chemistry and mathematics was not great, nevertheless they have general professionally important abilities as high level of concentration and stability of attention, memory on numbers and symbols. Now we will look at abilities concerning biology where a high level of development of visual perception of colour; good development of concentration of attention (ability long time to concentrate on one object; a subject, not distracting on others); creative thinking; rich imagination; ability to notice minor alterations in surrounding conditions; development of a figurative visual memory; ability to make the important decisions quickly; analytical abilities are listed [3, p.69]. Comparing them with abilities to chemistry, it is easy to point, that good development of concentration of attention is unique general ability to both chemistry and biology sciences, in spite of we fixed essential correlative connection between these sciences in the Table 1 . These positions say that abilities and propensity must be studied even more deeply where psychophysiological and hereditary tendencies of development of these abilities are taken into account.

As it is known, the heredity side of psychological properties of the person was studied with the help of twins methods during many years. But also there is a method of dermatoglyphics [4], by using it we investigated the hereditary factors of many psychological traits of a person $[5,6,7,8]$. Utilizing the dermatoglyphics method and «Heredity regularity of psychological properties» [9] give us a huge possibility to investigate the hereditary sides of ability and propensity.

Summing up it is possible to tell, that abilities to exact sciences, especially to similar sciences, has a close connection among themselves. But the science chemistry in teenagers was represented similar both to exact, and to natural sciences. These data confirms, that the question of abilities and propensities in a psychological sciences are still not studied sufficiently. Abilities should be studied by means of hereditary indicators of the person, because they have the hereditary characteristics. By using a method of dermatoglyphics it is possible to study a natural origin of abilities. 


\section{References:}

1. Kadirov BR (1996) Izuchenie sklonnostey podrostkov. -Tashkent.: «Fan», 50.

2. Golomshtok AE (1963) Karta interesov. modifiscirovannaya metodika. Available: http://brunner.kgu.edu.ua (Accessed: 05.11.2014)

3. Romanova ES (2003) 99 populyarnih professiy. Psixologicheskiy analiz I professiogrammi. 2-e izd-e. SPb.: Piter, 464.

4. Aкbarova SN (2014) Dermatoglyphics analyze of psychological phenomena. Vestnik of Tajik Technical University, 25, pp. 142-144.

5. Akbarova SN (2014) Hereditary reflection of volition of the person. GESJ: Education Sciences and psychology, 30, pp. 20-23.
6. Акbarova SN, Matveeva AA (2014) Hereditary reflection of preconditions of aggression of the person. Topical Issues of Humanities \& Social Sciences, 34, pp.103-105.

7. Yakubova SN (2003) Neyrotizm hususiyatining fiziognomika va dermatoglifika asosidagi talqini. Pedagogik ta'lim, 4, pp. 9-11.

8. Yakubova SN (2003) Mardlik hususiyatining kelib chiqishi. Xalq ta'limi, 6, pp.69-71.

9. Akbarova SN (2014) Heredity regularity of psychological properties of person. ISJ Theoretical \& Applied Science, 02 (10): 132134. Doi:

http://dx.doi.org/10.15863/TAS.2014.02.10.21 